\title{
Peningkatan Kemampuan Praktik pada Perkuliahan Micro Konseling dengan Modeling Simbolis
}

\author{
Hanung Sudibyo ${ }^{1}$, M. Arif Budiman $\mathrm{S}^{2}$, Nita Fitria ${ }^{3}$, Edy Irawan ${ }^{4}$ \\ 12 Program Studi Bimbingan dan Konseling, Universitas Pancasakti Tegal \\ ${ }^{3} 4$ Program Studi Bimbingan dan Konseling, Universitas Muhammadiyah Pringsewu \\ hanungsudibyo@yahoo.co.id
}

\begin{abstract}
Abstrak
The purpose of this study is to improve practical skills in micro counseling lectures with symbolic modeling techniques. Based on the results of observations and interviews in the initial study, 10 students were not able to practice counseling. The method used in this research is the guidance and counseling action research method. This research is a collaborative research between the Guidance and Counseling Study Program at the University of Pancasakti Tegal and the Guidance and Counseling Study Program at the University of Muhammadiyah Pringsewu Lampung. The subjects of this study were $256 \mathrm{~A}$ students of the Guidance and Counseling Study Program at the Pancasakti University, Tegal and 30 students in the 6th Semester of the Guidance and Counseling Study Program at the Muhammadiyah University of Pringsewu Lampung. The data collection methods in this study were interviews, observations and document studies. The data analysis technique in this study used quantitative descriptive analysis using the percentage formula. The results of the study explain that the ability to practice counseling in micro counseling courses can be improved by using symbolic modeling techniques by providing examples or models in the form of video shows of classical, individual and group counseling practices to students.
\end{abstract}

Keywords: ability, micro counseling, symbolic modeling

\section{PENDAHULUAN}

Wabah virus corona sangat berdampak bagi kita semua. Sudah sekitar 1,5 tahun lebih kita melawan wabah virus corona dengan melakukan berbagai hal, salah satunya menghindari kerumunan. Pemerintah memberlakukan kebijakan penutupan berbagai tempat untuk menghindari penyebaran virus corona yang semakin tinggi. Salah satu tempat yang ditutup adalah bidang Pendidikan. Sekolah tidak boleh menyelenggarakan kegiatan pembelajaran di sekolah, dan pembelajaran tetap dilakukan dengan jarak jauh. Bidang pendidikan dari tingkat PAUD sampai dengan Perguruan Tinggi harus melakukan inovasi pengembangan model pembelajaran atau pelayanan dengan jarak jauh. Teknologi informasi menjadi hal yang utama dalam mendukung program belajar jarak jauh. Pendidik harus melakukan inovasi pembelajaran jarak jauh serta mampu menggunakan berbagai peralatan atau aplikasi teknologi informasi dalam mendukung kegiatan pembelajaran.

Berbagai macam aplikasi yang dapat digunakan pendidik dalam memberikan pembelajaran jarak jauh kepada peserta didik sudah tersedia diantaranya ada google 
classroom, zoom, google meet dst. Pembelajaran jarak jauh baik di tingkat sekolah dasar sampai dengan perguruan tinggi sudah dilaksanakan dengan bantuan aplikasi tersebut. Pembelajaran jarak jauh tingkat perguruan tinggi memang tidak begitu bermasalah, karena mahasiswa sudah mampu belajar dan dikondisikan sebagai orang dewasa. Namun pembelajaran jarak jauh di perguruan tinggi tetap mengalami permasalahan yaitu untuk mata kuliah yang bersifat praktik. Salah satunya mata kuliah micro konseling yang seharusnya pembelajaran praktik di ruang laboratorium bimbingan dan konseling, namun dengan adanya wabah virus corona ini dilakukan dengan pembelajaran jarak jauh secara daring.

Mata kuliah micro konseling merupakan mata kuliah praktik pada program studi bimbingan dan konseling universitas pancasakti tegal serta pada program studi bimbingan dan konseling universitas muhammadiyah pringsewu lampung. Mata kuliah ini bertujuan melatih keterampilan praktik konseling mahasiswa baik bentuk klasikal, individu maupun kelompok. Jadi baik teori maupun praktik pada mata kuliah sebelumnya, diperkuat dengan praktik di mata kuliah micro konseling ini. Mata kuliah micro konseling ini sebagai persiapan mahasiswa untuk praktik pengalaman lapangan atau praktik di sekolah. Mahasiswa akan mempunyai bekal praktik yang profesional baik ketika menjadi mahasiswa maupun kelak setelah lulus atau bekerja. Mahasiswa juga secara tidak langsung ketika praktik di sekolah atau luar kampus, merupakan ajang promosi program studi gratis. Jika mahasiswa yang praktik memiliki kemampuan praktik maka kepercayaan akan ada pada masyarakat sekolah untuk mendaftarkan diri pada program studi bimbingan dan konseling. Utamanya adalah dengan dilatih praktik, maka mahasiswa dapat memberikan pelayanan konseling lebih baik kepada peserta didik di sekolah.

Kemampuan adalah kapasitas seorang individu untuk melakukan beragam tugas dalam suatu pekerjaan. Kemampuan adalah sebuah penilaian terkini atas apa yang dapat dilakukan seseorang (id.wikipedia.org). Kemampuan (ability) adalah kecakapan atau potensi menguasai suatu keahlian yang merupakan bawaan sejak lahir atau merupakan hasil latihan atau praktek dan digunakan untuk mengerjakan sesuatu yang diwujudkan melalui tindakannya. Kemampuan praktik pada penelitian ini merupakan kecakapan melakukan praktik konseling pada mata kuliah micro konseling dari hasil latihan atau praktik.

Hasil penelitian Eurika (2016) dengan judul penelitian kemampuan praktik mengajar mahasiswa PPL prodi pendidikan biologi universitas muhammadiyah jember tahun akademik 2015/2016 di SMP dan SMA pada kegiatan pendahuluan termasuk dalam kriteria sangat baik ( 88 dan $86 \%$ ), pada kegiatan inti termasuk dalam kriteria sangat baik (antara $83-91 \%$ ), dan pada kegiatan penutup termasuk dalam kriteria sangat baik (87 dan 84\%). Hasil penelitian tersebut dapat disimpulkan bahwa kemampuan praktik mahasiswa PPL prodi pendidikan biologi tergolong baik, namun perlu ditingkatkan dengan melakukan pelatihan praktik pada perkuliahan atau melakukan inovasi pembelajaran praktik.

Berdasarkan hasil studi awal dengan melakukan observasi pembelajaran daring mata kuliah micro konseling pada program studi bimbingan dan konseling universitas pancasakti tegal yang berjumlah 25 mahasiswa semester 6A diperoleh 10 mahasiswa belum mampu praktik. Sedangkan hasil observasi pembelajaran daring mata kuliah micro konseling pada program studi bimbingan dan konseling universitas muhammadiyah pringsewu lampung yang berjumlah 30 mahasiswa semester 6 diperoleh 12 mahasiswa belum mampu praktik. Berdasarkan hasil wawancara terhadap mahasiswa yang belum mampu praktik diperoleh bahwa pembelajaran jarak jauh untuk mata kuliah praktik perlu didukung dengan contoh atau model yang dapat 
memberikan motivasi mahasiswa. Maka dalam penelitian ini menggunakan teknik modelling simbolis untuk meningkatkan kemampuan praktik mahasiswa pada mata kuliah micro konseling.

Komalasari, Wahyuni, dan Karsih (2011) menjelaskan bahwa modeling merupakan belajar melalui observasi dengan menambahkan atau mengurangi tingkah laku yang teramati, menggeneralisir berbagai pengamatan sekaligus, dan melibatkan proses kognitif. Siswa dapat mengamati tingkah laku model yang digunakan sehingga diharapkan siswa termotivasi dengan apa yang ditampilkan. Teknik modeling memilki konsep komponen dari suatu strategi dimana konselor menyediakan demonstrasi tentang tingkah laku yang menjadi tujuan. Model yang digunakan dapat sesungguhnya (langsung) dan simbolis. Model yang sesungguhnya adalah orang, yaitu konselor, dan simbolis menggunakan model berupa tayangan video. Modeling simbolis disajikan melalui bahan-bahan tertulis, audio, video, film atau slide. Modeling simbolis dapat disusun untuk klien individu atau dapat distandarisasikan untuk kelompok klien (Nursalim, 2005).

Berdasarkan hasil penelitian Arumsari (2016) tentang konseling individual dengan teknik modeling simbolis terhadap peningkatan kemampuan kontrol diri diperoleh bahwa Konseling individu dengan teknik modeling simbolis efektif mengembangkan kontrol diri tiga siswa subjek penelitian pada semua sapek kontrol diri yaitu perasaan dan tingkah laku, disiplin, emosi dan nafsu. Penelitian juga dilakukan oleh Sari dkk (2017) tentang penerapan teknik modeling simbolis dalam meningkatkan perilaku tolerasi siswa kelas V SD Negeri 25 Banda Aceh diperoleh bahwa adanya peningkatan dan perubahan perilaku toleransi siswa kelas V SD Negeri 25 Banda Aceh setelah diberikan teknik modeling simbolis.

Tujuan dari penelitian ini yaitu untuk meningkatkan kemampuan praktik pada perkuliahan micro konseling dengan teknik modeling simbolis.

\section{METODE}

Metode yang digunakan dalam penelitian ini adalah metode penelitian tindakan bimbingan dan konseling. Hidayat \& Badrujaman (2012) mengatakan penelitian tindakan bimbingan dan konseling adalah suatu kegiatan yang dilakukan untuk mempelajari suatu masalah, mencari solusi, serta melakukan perbaikan atas suatu program sekolah atau kelas yang khusus. penelitian tindakan secara garis besar terdapat 4 tahapan yang lazim dilalui yaitu (1) Perencanaan, (2) Pelaksanaan, (3) Pengamatan, dan (4) Refleksi. Penelitian ini merupakan penelitian kolaborasi antara program studi bimbingan dan konseling universitas pancasakti tegal dengan program studi bimbingan dan konseling universitas muhammadiyah pringsewu lampung. Subyek penelitian ini yaitu 25 mahasiswa sementer $6 \mathrm{~A}$ program studi bimbingan dan konseling universitas pancasakti tegal dan 30 mahasiswa semester 6 program studi bimbingan dan konseling universitas muhammadiyah pringsewu lampung. Metode pengumpul data dalam penelitian ini berupa wawancara, observasi dan studi dokumen. Teknik analisis data dalam penelitian ini menggunakan analisis deksriptif kuantitatif dengan menggunakan rumus prosentase yaitu dengan cara menjumlahkan skor nilai siswa kemudian dicari rata-rata skor. Untuk menganalisis datanya menggunakan rumus persentase, dimana skor yang diperoleh dibagi dengan skor total kemudian dikalikan dengan $100 \%$. 


\section{HASIL DAN PEMBAHASAN}

Berdasarkan hasil observasi pada studi awal sebelum penelitian, diperoleh hasil terdapat 10 mahasiswa dari 25 mahasiswa semester 6A program studi bimbingan dan konseling universitas pancasakti tegal belum mampu praktik konseling pada perkuliahan micro konseling secara daring, sedangkan hasil observasi pada program studi bimbingan dan konseling universitas muhammadiyah pringsewu lampung terdapat 12 mahasiswa dari 30 mahasiswa semester 6 yang belum mampu praktik konseling pada perkuliahan micro konseling secara daring. Untuk lebih jelasnya dapat dilihat pada tabel 1 dan 2 berikut :

Tabel 1 Hasil Observasi Kemampuan Praktik Awal (Mahasiswa UPS Tegal)

\begin{tabular}{ccc}
\hline Kategori & Frekuensi & Persen (\%) \\
\hline Tinggi & 0 & 0 \\
Sedang & 15 & 60 \\
Rendah & 10 & 40 \\
\hline
\end{tabular}

Tabel 2 Hasil Observasi Kemampuan Praktik Awal (Mahasiswa UMPRI Lampung)

\begin{tabular}{ccc}
\hline Kategori & Frekuensi & Persen (\%) \\
\hline Tinggi & 0 & 0 \\
Sedang & 18 & 60 \\
Rendah & 12 & 40 \\
\hline
\end{tabular}

Berdasarkan hasil wawancara memperoleh hasil bahwa mahasiswa yang belum mampu praktik konseling pada mata kuliah micro konseling dengan pembelajaran jarak jauh secara daring dikarenakan mahasiswa merasa kebingungan dan membutuhkan suatu model atau contoh dalam praktik konseling secara daring. Untuk itu perlu dilakukan inovasi pembelajaran jarak jauh praktik konseling pada mata kuliah micro konseling dengan teknik modeling simbolis. Modeling simbolis pada penelitian ini berupa video rekaman praktik konseling klasikal, individu dan kelompok yang diperoleh dari P4TK Penjas BK Parung Bogor.

\section{Siklus I}

1. Perencanaan

Perencanaan tindakan pada siklus I dilakukan dengan $2 x$ pertemuan :

a. Pertemuan pertama : 1) Menyiapkan link pembelajaran daring, 2) Menyiapkan rencana pelaksanaan layanan, 3) Menyiapkan materi pembelajaran daring, 4) Menyiapkan video praktik konseling baik klasikal, individu maupun kelompok.

b. Pertemuan kedua : 1) Menyiapkan link pembelajaran daring, 2) Menyiapkan video hasil rekaman mahasiswa praktik dalam bentuk link youtube atau google drive

2. Pelaksanaan

Pelaksanaan tindakan pada siklus I dilakukan dengan 2x pertemuan : 
a. Pertemuan pertama : 1) Menjelaskan tujuan dan tata cara pelaksanaan perkuliahan daring micro konseling, 2) Membagi mahasiswa yang mendapat tugas praktik klasikal, individu atau kelompok, 3) Menyetel video praktik konseling baik klasikal, individu maupun kelompok, 4) Memberi tugas mahasiswa untuk praktik klasikal, individu atau kelompok sesuai pembagian tugas, 5) Meminta mahasiswa merekam hasil praktik klasikal, individu atau kelompok tersebut dan dikirim ke peneliti dalam bentuk link youtube atau google drive

b. Pertemuan kedua : Menonton bersama video hasil rekaman mahasiswa praktik konseling baik klasikal, individu atau kelompok

3. Observasi

Observer melakukan pengamatan terhadap pelaksanaan tindakan pada siklus I. Hasil observasi oleh pengamat pada mahasiswa program studi bimbingan dan konseling universitas pancasakti tegal yang berjumlah 25 mahasiswa terdapat 5 mahasiswa yang masih belum mampu praktik konseling. Sedangkan hasil observasi oleh pengamat pada mahasiswa program studi bimbingan dan konseling universitas muhammadiyah pringsewu lampung berjumlah 30 mahasiswa terdapat 6 mahasiswa yang masih belum mampu praktik konseling.

4. Refleksi

Refleksi diperoleh dari hasil wawancara dan observasi terhadap mahasiswa. Berdasarkan catatan dari peneliti dan observer diperoleh hasil :

a. Masih terdapat mahasiswa yang belum mampu praktik konseling klasikal, individu atau kelompok

b. Rencana perbaikan dan inovasi yaitu setelah mahasiswa menonton hasil rekaman praktik konseling sendiri maka mahasiswa diminta untuk melakukan evaluasi kekurangan diri serta peneliti memberi masukan perbaikan praktik konseling

Siklus II

1. Perencanaan

Perencanaan tindakan pada siklus II dilakukan dengan $2 \mathrm{x}$ pertemuan :

a.Pertemuan pertama : 1) Menyiapkan link pembelajaran daring, 2) Menyiapkan rencana pelaksanaan layanan, 3) Menyiapkan materi pembelajaran daring, 4) Menyiapkan video praktik konseling baik klasikal, individu maupun kelompok.

b.Pertemuan kedua : 1) Menyiapkan link pembelajaran daring, 2) Menyiapkan video hasil rekaman mahasiswa praktik dalam bentuk link youtube atau google drive

2. Pelaksanaan

Pelaksanaan tindakan pada siklus II dilakukan dengan 2x pertemuan :

a.Pertemuan pertama : 1) Menjelaskan tujuan dan tata cara pelaksanaan perkuliahan daring micro konseling, 2) Membagi mahasiswa yang mendapat tugas praktik klasikal, individu atau kelompok, 3) Menyetel video praktik konseling baik klasikal, individu maupun kelompok, 4) Memberi tugas mahasiswa untuk praktik klasikal, individu atau kelompok sesuai pembagian tugas, 5) Meminta mahasiswa merekam hasil praktik klasikal, individu atau kelompok tersebut dan dikirim ke peneliti dalam bentuk link youtube atau google drive

b.Pertemuan kedua : 1) Menonton bersama video hasil rekaman mahasiswa praktik konseling baik klasikal, individu atau kelompok, 2) setelah mahasiswa menonton hasil rekaman praktik konseling sendiri maka mahasiswa diminta untuk melakukan evaluasi kekurangan diri serta peneliti memberi masukan perbaikan praktik konseling

3. Observasi 
Observer melakukan pengamatan terhadap pelaksanaan tindakan pada siklus II. Hasil observasi oleh pengamat pada mahasiswa program studi bimbingan dan konseling universitas pancasakti tegal yang berjumlah 25 mahasiswa diperoleh hasil 25 mahasiswa sudah mampu praktik konseling. Sedangkan hasil observasi oleh pengamat pada mahasiswa program studi bimbingan dan konseling universitas muhammadiyah pringsewu lampung berjumlah 30 mahasiswa diperoleh hasil 30 mahasiswa sudah mampu praktik konseling.

4. Refleksi

Refleksi diperoleh dari hasil wawancara dan observasi terhadap mahasiswa. Berdasarkan catatan dari peneliti dan observer diperoleh hasil :

a.Mahasiswa sudah mampu praktik konseling klasikal, individu atau kelompok

b. Kekurangan pada siklus I sudah diperbaiki dengan inovasi pada siklus II.

Hasil observasi siklus I dan siklus II dapat dilihat pada tabel 3 dan 4 berikut:

Tabel 3 Hasil Observasi Kemampuan Praktik Siklus I dan Siklus II (Mahasiswa UPS Tegal)

\begin{tabular}{ccccc}
\hline & \multicolumn{2}{c}{ Siklus I } & \multicolumn{2}{c}{ Siklus II } \\
\cline { 2 - 5 } Kategori & Frekuensi & Persen $\%$ & Frekuensi & Persen \% \\
\hline Tinggi & 15 & 60 & 22 & 88 \\
Sedang & 5 & 20 & 3 & 12 \\
Rendah & 5 & 20 & 0 & 0 \\
\hline
\end{tabular}

Tabel 4 Hasil Observasi Kemampuan Praktik Siklus I dan Siklus II (Mahasiswa UMPRI Lampung)

\begin{tabular}{ccccc}
\hline & \multicolumn{2}{c}{ Siklus I } & \multicolumn{2}{c}{ Siklus II } \\
\cline { 2 - 5 } Kategori & Frekuensi & Persen $\%$ & Frekuensi & Persen \% \\
\hline Tinggi & 20 & 70 & 27 & 90 \\
Sedang & 3 & 10 & 3 & 10 \\
Rendah & 6 & 20 & 0 & 0 \\
\hline
\end{tabular}

Berdasarkan hasil observasi kemampuan praktik konseling mahasiswa program studi bimbingan dan konseling universitas pancasakti tegal pada siklus I dan Siklus II mengalami peningkatan sebesar $22 \%$, sedangkan hasil observasi kemampuan praktik konseling mahasiswa program studi bimbingan dan konseling universitas muhammadiyah pringsewu lampung sebesar $20 \%$.

\section{SIMPULAN}

Kemampuan praktik konseling pada mata kuliah micro konseling dapat ditingkatkan dengan teknik modeling simbolis dengan cara memberikan contoh atau model berupa tayangan video praktik konseling klasikal, individu maupun kelompok kepada mahasiswa. Perbaikan dan inovasi yaitu setelah mahasiswa menonton hasil rekaman praktik konseling sendiri maka mahasiswa diminta untuk melakukan evaluasi kekurangan diri serta peneliti memberi masukan perbaikan praktik konseling. 


\section{DAFTAR PUSTAKA}

Arumsari, Cucu. 2016. Konseling Individual dengan Teknik Modeling Simbolis terhadap Peningkatan Kemampuan Kontrol Diri. Jurnal Konseling Gusjigang Vol 2 No 1. https://jurnal.umk.ac.id/index.php/gusjigang/article/view/549

Eurika, Novy. 2016. Kemampuan Praktik Mengajar Mahasiswa PPL Prodi Pendidikan Biologi UNMUH Jember. Jurnal Biologi dan Pembelajaran Biologi Vol 1 No 2 http://jurnal.unmuhjember.ac.id/index.php/BIOMA/article/view/440

Hidayat, Rahmat Dede \& Badrujaman, Aip. 2012. Penelitian Tindakan dalam Bimbingan dan Konseling. Jakarta : Indeks

Komalasari, Gantina., Eka Wahyuni., dan Karsih. 2011. Teori dan Teknik Konseling. Jakarta: Indeks

Nursalim, M. 2005. Strategi Konseling. Surabaya: UNESA.

Sari, Putri Fakhrina., Yahya, Matunis., Fajriani. 2017. Penerapan Teknik Modeling Simbolis dalam Meningkatkan Perilaku Toleransi Siswa Kelas V SD Negeri 25 Banda Aceh. Jurnal Ilmiah Mahasiswa Bimbingan \& Konseling Vol 2 No 2 http://jim.unsyiah.ac.id/pbk/article/view/2796 